\title{
Assessing the Value of Distributed Solar Energy Generation
}

\author{
Damian Pitt $^{1} \cdot$ Gilbert Michaud $^{2}$
}

Published online: 19 July 2015

(C) Springer International Publishing AG 2015

\begin{abstract}
Solar energy has recently become the subject of heated policy debate across the United States, particularly at the state level. Proponents note that it provides a variety of environmental, public health, and economic development benefits for society and argue that it can help support electric grid operations. Many electric utilities, however, contend that the growth of customer-owned, distributed solar energy systems will create costs that the utilities must pass on to ratepayers. This debate has led to a wide range of technical reports seeking to quantify the costs and benefits of solar energy to electric utilities, ratepayers, and society at large. We review these studies, discuss the different perspectives that they represent, and identify the key variables that have shaped this value-of-solar debate. We conclude by discussing future research opportunities that could help to maximize the benefits of solar energy use while minimizing its potential negative impacts.
\end{abstract}

Keywords Solar energy · Electric utilities · Value of solar · Solar photovoltaic energy systems $\cdot$ Policy

This article is part of the Topical Collection on Urban Planning

Damian Pitt

dpitt@vcu.edu

Gilbert Michaud

michaudg1@vcu.edu

1 Urban and Regional Studies and Planning, L. Douglas Wilder School of Government and Public Affairs, Virginia Commonwealth University, P.O. Box 842028, 923 W. Franklin St., Richmond, VA, USA

2 Public Policy and Administration, L. Douglas Wilder School of Government and Public Affairs, Virginia Commonwealth University, P.O. Box 842028, 923 W. Franklin St., Richmond, VA, USA

\section{Introduction}

The recent rapid growth of solar energy use in the USA is met with approval by supporters who point to the many environmental and public health benefits that it provides, compared to conventional fossil fuel-based electrical generation. These benefits include the mitigation of greenhouse gas (GHG) emissions, a topic of global importance given that the USA is the world's second-leading producer of these climate change-inducing pollutants [1]. Investment in solar energy can also be an economic development driver, creating construction jobs and manufacturing opportunities. Solar energy proponents also argue that it can also be beneficial to electric utilities by saving them money on conventional generation fuels, avoiding new generation capacity investments, and reducing the strain on existing transmission and distribution infrastructure [2].

However, opponents, including many of those same electric utilities, contend that solar energy creates costs that must then be passed on to ratepayers. These concerns are most often raised in regard to distributed solar photovoltaic (PV) energy systems, i.e., small- to medium-sized solar energy conversion systems that one might place on the roof of a home or business. Of particular concern to utilities is the now-common practice of net-metering for grid-connected PV systems. Under this arrangement, a customer who owns a PV system can sell excess electricity back to the utility at times when the system produces more electricity than the building requires (e.g., on sunny afternoons). The customer then continues to buy electricity from the grid at night, or any other time when the PV system produces less energy than the building is consuming. Under net-metering, the customers only pay for the "net" amount of electricity they consume each month, at the retail electricity rate [3]. Some electric utilities now argue that this policy is unfair, because the retail electric rate is intended 
to cover not only the ongoing costs of daily electricity generation, but also the fixed costs of all the wires, poles, substations, and centralized generation facilities that make that electricity available. According to this argument, net-metering customers are effectively subsidized by non-net-metering customers, as the latter group ends up paying a larger share of the fixed costs that each group needs equally [4].

Furthermore, opponents contend that increased use of distributed, customer-owned solar energy systems could reduce utilities' revenue to the point that they cannot pay off existing investments in conventional generation infrastructure, creating "stranded asset" costs [5]. The utilities also argue that distributed solar PV systems could cause technical problems for the transmission and distribution grids. Finally, some suggest that any incentives to support distributed solar energy primarily benefit wealthier customers who can afford solar PV systems, which can amount to a regressive policy if it results in higher electricity costs for those customers who cannot afford solar [6].

The costs and benefits of solar power, and alternative energy sources in general, are coming under particular scrutiny now in light of the US Environmental Protection Agency's (EPA) proposed Clean Power Plan (CPP), which would regulate carbon dioxide $\left(\mathrm{CO}_{2}\right)$ emissions from existing power plants under section 111(d) of the Clean Air Act [7]. The plan establishes a nationwide goal of reducing those emissions to $30 \%$ below 2005 levels by the year 2030, along with statespecific emissions rate goals intended to reflect the unique energy market conditions in each state (e.g., the carbon dioxide $\left(\mathrm{CO}_{2}\right)$ emissions rate goal for Virginia under the CPP is $38 \%$ below 2005 levels by 2030) [8]. These emissions rate goals are based on analysis of the states' potential carbon dioxide $\left(\mathrm{CO}_{2}\right)$ reductions under each of four "building block assumptions:" coal plant efficiency, natural gas dispatch, renewable and nuclear generation, and demand-side energy efficiency [9]. This has led to extensive debate and analysis over the technical potential to achieve those targets, and the anticipated economic impacts of doing so, which requires an understanding of solar energy's potential contributions within each state and the associated costs and benefits.

In this article, we review the current policy debate on distributed solar energy and the ongoing research efforts to identify the true "value of solar" (VOS) for electric utilities, their customers, and society at large. We begin by summarizing the wide range of policies that some states have adopted to support distributed solar and the recent efforts by opponents to roll back those policies or create barriers to distributed solar energy use. We then provide a brief overview of the existing body of research on the costs and benefits of distributed solar energy, before discussing in greater detail the different variables typically analyzed in these VOS analyses. We conclude by identifying the key unanswered questions in the VOS debate and the implications of this debate for the broader field of urban and regional planning.

\section{The Policy Debate on Distributed Solar Energy}

Over the past $10-15$ years, many states have adopted one or more policies to enable or incentivize distributed solar PV investments. The most common, and most fundamental, of these is net-metering, which has been adopted in 45 of the 50 states. Over half of US states have a mandatory renewable portfolio standard (RPS), while seven others have a voluntary RPS program [10]. Under a mandatory RPS, electric utilities are required to meet annual targets for obtaining a portion of their electricity supply from renewable sources such as solar and wind power (e.g., $10 \%$ by the year 2020). Sixteen of these states include a "solar carve-out," which requires a small portion of each utility's energy mix to come specifically from solar [11]. States with a mandatory RPS typically allow utilities to meet their requirements by purchasing solar renewable energy credits (SRECs), which the owners of distributed solar PV systems can sell based on the amount of electricity that their systems create [12]. Owners of PV systems in states without a mandatory RPS can sometimes sell SRECs to outof-state utilities [13]. For example, system owners in Virginia can sell SRECs in the Pennsylvania market.

Beyond these policies, many states have adopted various additional financial incentives to encourage or support the deployment of customer-owned distributed solar energy systems. These include property, sales, or personal/corporate income tax incentives for system purchasers (beyond the 30\% income tax credit offered by the federal government through the end of 2016), grants or rebates, low- or zero-interest loans, or "feed-in tariffs" requiring utilities to purchase solar energy from producers at an above-market rate [14]. Finally, states can adopt enabling legislation (where necessary) to allow new "third-party" business models for distributed solar PV systems, such as solar leases or power purchase agreements, or to allow "community" or "shared" solar arrangements.

The debate around distributed solar energy has focused primarily around RPS and net-metering. In recent years, bills to repeal RPS laws have been introduced in 13 states [15]. These efforts had been unsuccessful until February, 2015, when West Virginia became the first state to repeal its RPS [16]. The movement against distributed solar energy has seen greater success by undermining net-metering arrangements through the application of "stand-by charges," which allow utilities to levy a monthly fee to owners of solar PV systems [17]. In 2011, Virginia became the first state to allow these charges, and in 2014, the state's largest electric utility gained approval to initiate stand-by charges for residential netmetered systems with a power capacity of $10 \mathrm{KW}$ or more 
$[18,19] .{ }^{1}$ Arizona also enacted a stand-by charge policy in early 2014. Similar policies have been considered in Georgia, Idaho, Maine, Vermont, and Wisconsin [20, 21].

\section{Understanding the Costs and Benefits of Distributed Solar Energy}

Over the past decade, the VOS issue has been tackled by a wide range of academics, technical consulting firms, non-profit organizations, and state and federal agencies, as shown in Table 1. These prior VOS studies reflect a variety of perspectives, methodologies, and assumptions. Many have been conducted on behalf of either an electric utility, the solar energy industry, or a state public utility commission (the agency in each state charged with regulating the electric utility industry). Some focus on the costs and benefits of solar for electric utilities only [e.g., $[22,23]$, while others expand the analysis to include broader societal impacts [e.g., [24-26]. Others provide important summary analyses of VOS issues and methodologies [27•, 28•, 29•].

While thousands of academic research articles have been published about various technical, economic, and policy issues around solar energy, surprisingly few address the VOS issue directly. The best example dates back to 2005, when Duke et al. quantified the value of PV electricity in two US regions (southern California and northern Illinois) based on a wide range of utility operations and environmental impact variables [30].

Many of the prior VOS studies, particularly those completed on behalf of the solar energy industry, quantified the benefits of solar energy while downplaying its potential costs. Several of these studies found the benefits to equal around US $\$ 0.10-$ US $\$ 0.20$ per kilowatt-hour [27•], but others estimated them as high as US\$0.25-US\$0.35 per kilowatt-hour in some states $[24,48]$. Other studies, mostly utility-sponsored, focus primarily on the costs to utilities of PV integration $[39,56,57]$. For example, a 2011 report by the Virginia State Corporation Commission examined the potential costs of increasing net-metered distributed solar power to $1 \%$ of each utility's peak load, crediting solar with only the avoided cost that utilities would otherwise have to pay to generate and transmit that electricity, plus a small amount of avoided generation capacity costs. As a result, the study found a net cost to utilities of US $\$ 0.03$ per kilowatt-hour of solar energy

\footnotetext{
${ }^{1}$ The installed capacity of a solar or other electricity generating system represents the total electrical power that it can generate in a given moment at peak performance. Power is measured in watts $(\mathrm{W})$, kilowatts $(\mathrm{KW}$, or $1000 \mathrm{~W})$, or megawatts $(\mathrm{MW}$, or $1000 \mathrm{KW})$. The energy that a system generates is a function of its power production over time (Power $\times$ Time $=$ Energy) and is measured in watt-hours, kilowatthours (KWh), or megawatt-hours (MWh).
}

produced, which when spread across the entire customer base would only increase average annual customer bills by less than $0.5 \%[51,55]$. Similarly, an analysis by the Pacific Northwest National Laboratory, for Duke Energy, found that PV integration costs would be around US\$0.03-US\$0.04 per kilowatt-hour if PV capacity reaches 3-7\% of peak loads by the year 2016 or 2018 , but could rise as high as US $\$ 0.098$ per kilowatt-hour if PV capacity reaches much higher penetrations (20\% of peak capacity) over the long term [57]. Finally, a 2010 study completed for NV Energy found that net-metered distributed generation (mostly PV) would create a net revenue shift of between US\$ 6 million and US\$10 million, assuming a market penetration of $1 \%$ of total statewide energy generation. Based on the utility's current customer count of just over 1.2 million, this works out to approximately US\$5-US\$8 per customer per year. At higher market penetration levels ( 9 and $15 \%$ ), the revenue shift is estimated at US\$50 million to US\$150 million, or about US $\$ 40$ to US $\$ 125$ per customer $[37,59]$.

A few independent analyses, weighing both benefits and costs, bear mentioning. A 2013 study by the Vermont Public Service Department [56] found a statewide net cost/benefit of essentially zero for new distributed PV systems installed in 2013, assuming no greenhouse gas (GHG) values, but a benefit of US\$0.043 per kilowatt-hour if GHGs are included. Another study from 2013, performed on behalf of Arizona Public Service, found that, under current conditions, distributed solar energy in that utility's service area provides a net benefit of around US $\$ 0.07$ to US $\$ 0.08$ per kilowatt-hour after accounting for a full range of costs and benefits [35]. Most recently, a 2015 study for the Public Service Commission of Mississippi found a net-positive total resource cost, of around US $\$ 0.025$ per kilowatt-hour, for a "Mid-Case" scenario based on moderate assumptions for each of the eight VOS variables considered in the study. The accompanying "All-Low" and "All-High" scenarios, based on the least and most-favorable assumptions for solar energy, found a net cost of roughly US $\$ 0.02$ per kilowatt-hour and a net benefit of about US\$0.06 per kilowatt-hour respectively [50].

\section{Factors in Value-of-Solar Analysis}

While each VOS report is unique, the more comprehensive analyses incorporate many of the same variables in calculating the costs and benefits of solar energy. These are discussed as follows.

\section{Avoided Energy Costs}

This variable simply accounts for the avoided cost that a utility would otherwise have to pay to purchase or generate an equivalent amount of electricity. This value varies, depending on 
Table 1 Notable VOS studies by lead author type, client type, and state(s)

\begin{tabular}{|c|c|c|c|c|}
\hline \multirow[t]{2}{*}{ Author type } & \multicolumn{4}{|l|}{ Client type } \\
\hline & State government & Electric utility & Solar industry & Other/NA \\
\hline Consultant & $\begin{array}{l}\text { E3 Inc., } 2010 \text { (CA) [31] } \\
\text { E3 Inc., } 2011 \text { (CA) [32] } \\
\text { E3 Inc., } 2012 \text { (CA) [22] } \\
\text { E3 Inc., } 2014 \text { (NV) [33] } \\
\text { SEE Inc., } 2014 \text { (MS) [34] }\end{array}$ & $\begin{array}{l}\text { Beach, } 2013 \text { (AZ) [35] } \\
\text { Beck, } 2009 \text { (AZ) [36] } \\
\text { Hoff, } 2006 \text { (TX) [23] } \\
\text { Navigant, } 2010 \text { (NV) [37] } \\
\text { Rábago, } 2012 \text { (TX) [38] } \\
\text { SAIC, } 2013 \text { (AZ) [39] } \\
\text { XCEL, } 2013 \text { (CO) }{ }^{\mathrm{a}}[40]\end{array}$ & $\begin{array}{l}\text { Beach, } 2013 \text { (CA) [41] } \\
\text { Beach, } 2013 \text { (CO) [42] } \\
\text { Beach, } 2013 \text { (NC) [43] } \\
\text { Cliburn, } 2013 \text { (USA) [44] } \\
\text { Perez, } 2008 \text { (NY) [26] } \\
\text { Perez, } 2012 \text { (NJ/PA) [24] } \\
\text { Weiss, } 2012 \text { (TX) [45] }\end{array}$ & 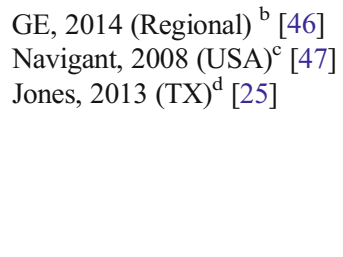 \\
\hline Non-profit & & & Smeloff, 2005 (CA) [48] & $\begin{array}{l}\text { IREC, } 2013 \text { (USA) [28•] } \\
\text { Fine, } 2014 \text { (USA) [49] } \\
\text { MEI, } 2015 \text { (MO) [50] } \\
\text { RMI, } 2013 \text { (USA) [27•] }\end{array}$ \\
\hline Academic & Pitt, 2014 (VA) [51] & & & $\begin{array}{l}\text { Duke, } 2005 \text { (USA) [30] } \\
\text { Perez, } 2011 \text { (USA) [52] }\end{array}$ \\
\hline Government & $\begin{array}{l}\text { LBNL, } 2012 \text { (CA) [53] } \\
\text { NYSERDA, } 2012 \text { (NY) [54] } \\
\text { VA SCC, } 2011 \text { (VA) [55] } \\
\text { VT PSD, } 2013 \text { (VT) [56] }\end{array}$ & PNNL, 2014 (NC/SC) [57] & & $\begin{array}{l}\text { LBNL, } 2014 \text { (USA) [58] } \\
\text { NREL, } 2014 \text { (USA) [29•] }\end{array}$ \\
\hline
\end{tabular}

${ }^{a}$ Study completed by an electric utility on its own behalf, in response to state agency ruling

${ }^{\mathrm{b}}$ Study completed by consultant on behalf of PJM Interconnection, LLC (PJM is a regional transmission organization that oversees the activity of wholesale electricity in portions or the entirety of 13 states, as well as Washington D.C.)

${ }^{\mathrm{c}}$ Study completed by consultant on behalf of National Renewable Energy Laboratory (NREL)

${ }^{\mathrm{d}}$ Study completed by consultant and non-profit on behalf of City of San Antonio

when the solar energy is produced, which determines the type of electricity generation that is being displaced. Avoided energy costs are very small at times of low demand, when power is primarily provided by baseload generation facilities (typically nuclear or coal-fired power plants) that run all of the time and are difficult to turn on and off. However, solar energy generated at times of higher demand, such as in the middle of a hot summer day, would displace power from "intermediate" or "peaking" plants that are increasingly more expensive to operate [36]. This variable sometimes includes a multiplier (e.g., 7-8 \% more) to account for line losses in transmitting the avoided energy to its point of consumption [48].

\section{Generation Capacity}

Proponents argue that distributed solar energy can help utilities avoid the cost of future power plants that would otherwise be built to meet rising electricity demand. For example, a 2013 study estimated the avoided generation capacity benefit of distributed solar in California at US\$0.044 per kilowatt-hour [41]. However, utilities counter that even with high levels of solar PV market penetration, the same amount of conventional generation capacity would be needed to meet demand at times when solar energy systems are not performing (e.g., at night) [60•]. Electric utilities are particularly concerned that customer-owned solar energy production could reduce the revenue they need to pay for existing generation infrastructure, thus turning those facilities into stranded assets [5]. This problem could be mitigated if increased solar energy use was paired with improved energy storage capability, so that some of the electricity produced by solar energy facilities could be held back and then released to the grid in the evening.

\section{Transmission and Distribution Grid Impacts}

Increased solar energy use could have potential positive or negative impacts on electricity transmission and distribution (T\&D) systems. However, these impacts would be highly location-specific and are difficult to quantify in broad terms. Distributed solar energy can, at least in theory, avoid the need for new transmission infrastructure by concentrating generation closer to its point of use. The aforementioned 2013 Arizona study calculated the T\&D savings from solar to be US\$0.021 per kilowatt-hour [35]. Nonetheless, such savings would only be possible if the solar energy is produced at peak demand periods, when transmission needs are greatest.

Distributed solar energy systems can also potentially help reduce electricity distribution infrastructure costs, particularly when the majority of the energy they produce is consumed onsite. However, such is not necessarily the case, as net-metered systems return much of their electricity back to the distribution grid. In this case, concentrations of distributed solar 
generation can pose technical challenges that reduce the effectiveness and reliability of the distribution grid. As with generation capacity, some of the distribution system problems could likely be mitigated through improved energy storage technology, as well as through micro-grids and a more robust urban distribution infrastructure employing "smart grid" technology $[61,62]$.

Along these lines, some VOS studies also credit distributed solar with the potential to increase grid reliability and resiliency by reducing the likelihood of power outages. This potential benefit is occasionally recognized by the utility industry [62], but very few studies attempt to quantify this highly complex variable. Some studies also attribute a variety of other ancillary grid support benefits to distributed solar energy [27•]. However, these would seem to be relatively minor values, even in a high solar energy penetration scenario.

\section{Natural Gas Market Impacts}

Certain VOS studies attempt to quantify the impact that the increased use of distributed solar power would have on the natural gas market. One argument is that distributed solar provides utilities with a hedge against the volatility of natural gas prices, thus saving money that they would otherwise spend on risk mitigation investments. Some studies also suggest that distributed solar can reduce the overall need for natural gas over the long term, thus leading to reduced prices in the wholesale gas market [27•]. An analysis of the New Jersey and Pennsylvania electricity markets estimated significant value for these natural gas impacts, ranging from US\$0.025 to US\$0.027 per kilowatt-hour for the fuel price hedge and US\$0.035 to US\$0.069 per kilowatt-hour for the market price impact [24], based on an assumed solar PV market penetration equal to $15 \%$ of peak electricity loads. However, such natural gas market impacts seem unlikely in the short to medium term given current market penetration rates.

\section{Environmental Benefits}

Solar energy provides several types of environmental and public health benefits, the most obvious of which come from the avoided air pollution and GHG emissions from fossil fuels that would have otherwise been consumed. Solar energy also provides ongoing indirect environmental benefits via avoided impacts from fuel extraction (e.g., coal mining, natural gas drilling, etc.) and by-product disposal (e.g., coal fly ash, spent fuel rods).

Existing VOS studies vary greatly in their approach to the broader societal benefits of solar energy, such as environmental and economic development impacts. The electric utility industry tends to argue that such "non-energy" benefits should not be factored into the cost of electricity rates [60•]. As such, studies conducted by or on behalf of electric utilities and state public utility commissions often do not touch on environmental issues [36, 39]. A few notable exceptions include studies for the City of Austin's municipal electric utility [23, 38] and the public utility commissions of California [22, 32], Mississippi [34], and Arizona [35]. Generally speaking, VOS studies performed by or on behalf of the solar energy industry do include the environmental benefits of solar [24, $43]$, as do studies by solar advocacy organizations [25, 41, 48], academics [30, 51], and federal agencies [29, 47]. Some calculate separate values for specific environmental benefits such as criteria air pollution and GHG emissions, while others use a more general environmental benefit value [27•].

Quite a number of academic research articles have addressed the environmental impacts of solar energy use. However, most focus on utility-scale solar installations, rather than distributed solar, and do not quantify those impacts on a cost per kilowatt-hour basis [63-65].

\section{Economic Development}

The economic development impact of distributed solar is one of the more controversial and difficult VOS variables to quantify. A study by the Union of Concerned Scientists (UCS) found that a $25 \%$ national RPS would create nearly 300,000 jobs in renewable energy manufacturing, construction, operations, and other relevant fields, three times the number that would be created through equivalent production from fossil fuel-based energy [66]. Solar energy supporters also suggest that a strong clean energy economy can help to attract businesses that want to locate in areas with good environmental conditions and a high quality of life [50].

However, opponents argue that the job creation benefits would be negated if solar energy growth leads to job losses in conventional electricity generation, and that the broader economic impacts would actually be negative if increased solar energy use results in higher electricity prices. For instance, the New York State Energy Research and Development Authority (NYSERDA) estimated that the construction of $5000 \mathrm{MW}$ of solar PV in that state by the year 2025 , at a cost of US\$2.50-US\$3.50 per watt, would create a net loss of 750 jobs per year as a result of increased electricity rates and ensuing lost discretionary income [54].

Many VOS studies do not quantify an economic development benefit for distributed solar, and those that do address it in very general terms [e.g., [24]. However, the aforementioned UCS report and other studies focus on the issue directly, outside of a broader VOS context $[66,67]$. Such analysis is aided by the National Renewable Energy Laboratory (NREL) Jobs and Economic Development Impact (JEDI) model, an online tool for estimating jobs and earnings impacts of renewable energy projects across three main categories: project development/labor impacts, local revenue/supply chain impacts, and induced impacts [68]. 
Recently, studies have emerged that estimate the economic development benefits of solar energy in the context of the EPA's proposed Clean Power Plan [69]. For instance, the Advanced Energy Economy Institute and the Virginia Advanced Energy Industries Coalition found that in Virginia, distributed solar would create more construction and operations and maintenance $(\mathrm{O} \& \mathrm{M})$ jobs per megawatt than any other generation technology: $8.33 \mathrm{jobs} / \mathrm{MW}$ for small commercial solar and 14.50 for small residential, compared to 6.88 for nuclear, 1.33 for natural gas, and 1.05 for on-shore wind [70].

\section{Conclusions and Discussion}

The VOS debate is largely a matter of perspective, as the costs and benefits vary widely based on the time frame considered, assumed market penetration, and values incorporated. Including values for societal impacts, particularly environmental benefits, would seem to guarantee a net positive value in most cases. However, the negative environmental impacts of conventional electricity generation are generally not captured by existing regulatory and market structures, and as such, they are often not addressed in official studies for electric utilities and public utility commissions. Thus, the EPA Clean Power Plan proposal could greatly shift the VOS narrative, particularly if it leads to a robust national market for GHG credits.

Many of the utilities' concerns about distributed solar energy have logical merit, but one could argue that they are very premature. Studies that focus on current or near-future conditions and/or employ relatively low market penetration assumptions tend to find minimal grid integration costs for distributed solar, when considered on a per-customer basis, even without factoring in societal benefits [e.g., [37, 55, 56]. Meanwhile, data from the Interstate Renewable Energy Council shows that the total power capacity for distributed (non-utility) solar PV in the USA was $1875 \mathrm{MW}$ by the end of 2013 [71], which would equal about $0.2 \%$ of the total US electric power capacity according to the US Energy Information Administration (EIA) [72].

That being said, solar power is by far the fastest-growing electricity source in the USA. According to EIA data, utilityscale solar energy generation experienced an average annual growth rate (AAGR) of $160 \%$ from January 2010 to January 2015 , far higher than that of any conventional generation source, although it still accounts for only about $0.33 \%$ of the nation's electricity generation [73]. The IREC data shows that distributed PV capacity had an AAGR of about $41 \%$ from 2009 to 2013 [71]. Given those growth rates, and the fact that utilities must plan their electricity generation profiles 20 30 years in advance, the need certainly exists to anticipate the implications of much higher solar PV market penetration over coming decades.

The academic community has largely stood by the sidelines of this issue, but there is tremendous opportunity for interdisciplinary academic research that explores how we can continue the growth of solar energy (both distributed and utilityscale) while avoiding potential negative future impacts. Even some utilities agree that these challenges must be overcome, so that we can "enable a distributed energy future for all customers" [62]. For example, how can a transition to solar energy be paced so that it avoids the need for future additions of centralized generation capacity, while maintaining sufficient revenue to support existing baseload capacity and back-up power generation? What, if anything, can be done to adjust PV power generation and electricity demand curves to better synchronize their respective peaks? How can we increase distributed PV use without overloading electricity distribution networks? What steps can be taken to avoid regressive economic impacts from increased PV system ownership?

The more technical of these issues may be overcome through advances in smart grid applications and, in particular, energy storage technology. However, public policy solutions must also be explored. For instance, the question of distribution grid integration has interesting implications for urban planning, as the negative impacts can potentially be minimized when solar PV is concentrated in commercial districts [28•]. Similarly, larger community or shared solar PV projects can create fewer grid integration issues if sited near substations or distribution feeders that have excess capacity. Finally, policy and economic researchers could explore opportunities for adjusting electricity rate structures in a way that better captures the balance of fixed vs. variable costs involved in actually providing electricity service, such as higher monthly customer charges paired with lower rates for consumption per kilowatt-hour. However, any such shift should be paired with other changes, such as time-of-use rates, that reflect the value of solar energy delivered at high-demand periods and should include other mechanisms to ensure that the rate changes do not stymie the growth of solar energy.

\section{Compliance with Ethics Guidelines}

Conflict of Interest Damian Pitt and Gilbert Michaud declare that they have no competing interests.

Human and Animal Rights and Informed Consent This article does not contain any studies with human or animal subjects performed by any of the authors. 


\section{References}

Papers of particular interest, published recently, have been highlighted as:

- Of importance

1. Boden C, et al. 2011. Ranking of the world's countries by 2011 total $\mathrm{CO} 2$ emissions from fossil-fuel burning, cement production, and gas flaring. US Department of Energy Carbon Dioxide Information Analysis Center. [cited 2015 7/3/2015]. Available from: http://cdiac.ornl.gov/trends/emis/top2011.tot.

2. Natural Resources Defense Council, 2015. Renewable energy for America: harvesting the benefits of homegrown, renewable energy. [cited 2015 4/27/2015]. Available from: http://www.nrdc.org/ energy/renewables/solar.asp.

3. Baldwin Auck S, et al. 2014. Freeing the grid: best practices in state net metering policies and interconnection procedures. [cited 2015 1/7/2015]. Available from: www.freeingthegrid.org/wp-content/ uploads/2013/11/FTG_2013.pdf.

4. Edison Electric Institute. 2013. Straight talk about net metering. [cited 2015 4/27/2015]. Available from: http://www.eei.org/ issuesandpolicy/generation/NetMetering/Documents/Straight $\%$ 20Talk\%20About $\% 20$ Net $\% 20$ Metering.pdf.

5. Raskin D. 2013. The regulatory challenge of distributed generation. Harvard Business Law Review Online Volume 4 p. 38-51. [cited 2015 4/27/2015]. Available from: http://www.hblr.org/2013/12/theregulatory-challenge-of-distributed-generation/.

6. Institute for Energy Research. 2013. Net metering: false free market claims and a regressive green tax. [cited 2015 4/27/2015]. Available from: http://instituteforenergyresearch.org/analysis/net-meteringfalse-free-market-claims-and-a-regressive-green-tax/.

7. US Environmental Protection Agency. 2014. Fact sheet: clean power plan framework. [cited 2015 4/27/2015]. Available from: http:// www2.epa.gov/carbon-pollution-standards/fact-sheet-cleanpower-plan-framework.

8. Center for Climate and Energy Solutions. 2015. Proposed state emission rate targets. [cited 2015 4/27/2015]. Available from: http://www.c2es.org/federal/executive/epa/carbon-pollutionstandards-map.

9. US Environmental Protection Agency. 2014. Regulatory impact analysis for the proposed carbon pollution guidelines for existing power plants and emission standards for modified and reconstructed power plants. [cited 2015 4/27/2015]. Available from: http:// www2.epa.gov/sites/production/files/2014-06/documents/ 20140602ria-clean-power-plan.pdf.

10. Center for Climate and Energy Solutions. 2014. Climate action. [cited 2015 2/17/2015]. Available from: http://www.c2es.org/ docUploads/all-state-initiatives-feb-2014.pdf.

11. Zientara B. 2015. Why a state's solar carve out is so important. [cited 2015 3/2/2015]. Available from: http://www. solarpowerrocks.com/affordable-solar/states-solar-carveimportant/.

12. Burns J, Kang J. Comparative economic analysis of supporting policies for residential solar PV in the United States: solar renewable energy credit (SREC) potential. Energy Policy. 2012;44(1): 217-25.

13. Bird L, et al. 2011. Solar renewable energy certificate (SREC) markets: status and trends. National Renewable Energy Laboratory, Golden, CO. [cited 2015 3/2/2015]. Available from: http://apps3. eere.energy.gov/greenpower/pdfs/52868.pdf.

14. Database of State Incentives for Renewables and Efficiency. 2014. [cited 2015 3/2/2015]. Available from: http://www.dsireusa.org/.
15. Plumer B. 2013. State renewable-energy laws turn out to be incredibly hard to repeal. The Washington Post. [cited 2015 1/7/2015]. Available from: http://www.washingtonpost.com/blogs/wonkblog/ wp/2013/08/08/state-renewable-energy-laws-turn-out-to-be-reallyhard-to-repeal/.

16. Light J. 2015. Score one for ALEC: West Virginia is first state to repeal a renewable energy standard. Grist. [cited 2015 1/7/2015]. http://grist.org/news/score-one-for-alec-west-virginia-is-first-stateto-repeal-a-renewable-energy-standard/.

17. Warrick J. 2015. Utilities wage campaign against rooftop solar. The Washington Post. [cited 2015 1/7/2015]. Available from: http:// www.washingtonpost.com/national/health-science/utilitiessensing-threat-put-squeeze-on-booming-solar-roof-industry/2015/ 03/07/2d916f88-c1c9-11e4-ad5c-3b8ce89f1b89_story.html.

18. Shapiro C. 2011. Dominion to charge fee to heavy users of solar power. The Virginian-Pilot. [cited 2015 1/7/2015]. Available from: http://hamptonroads.com/2011/11/dominion-charge-fee-heavyusers-solar-power.

19. Virginia State Corporation Commission. 2014. Case summary for case number: PUE-2014-00026. [cited 2015 1/7/2015]. Available from: http://www.scc.virginia.gov/docketsearch.

20. North Carolina Clean Energy Technology Center. 2014. Standby \& fixed-cost charges and net-metering energy debates. [cited 2015 1/7/2015]. Available from: http://nccleantech.ncsu.edu/wpcontent/uploads/State-Status-of-NEM-Standby-+-Fixed-CostCharge-Debates_V2.pdf.

21. Turkel T. 2014. CMP wants Mainers who generate their own power to pay more. Portland Press Herald. [cited 2015 4/27/2015]. Available from: http://www.pressherald.com/2014/03/11/cmp wants_maine_self-generators_who_feed_grid_using_solar_ wind to pay more $/$.

22. Energy and Environmental Economics (E3). 2012. Technical potential for local distributed photovoltaics in California, preliminary assessment. Report for the California Public Utilities Commission. [cited 2015 3/2/2015]. Available from: http://www.cpuc.ca.gov/nr/ rdonlyres/8a822c08-a56c-4674-a5d2-099e48b41160/0/ ldpvpotentialreportmarch2012.pdf.

23. Hoff T, et al. 2006. The value of distributed photovoltaics to Austin Energy and the city of Austin. Clean Power Research, for Austin Energy. [cited 2015 3/2/2015]. Available from: www.cleanpower. com/wp-content/uploads/034_PV_ValueReportAustinEnergy.pdf.

24. Perez R, et al. 2012. The value of distributed solar electric generation to New Jersey and Pennsylvania. Clean Power Research, for the MidAtlantic Solar Energy Industries Association \& Pennsylvania Solar Energy Industries Association. [cited 2015 3/2/2015]. Available from: www.mseia.net/site/wp-content/uploads/2012/05/MSEIA-FinalBenefits-of-Solar-Report-2012-11-01.pdf.

25. Jones N, Norris B. 2013. The value of distributed solar electric generation to San Antonio. Clean Power Research with Solar San Antonio, for the city of San Antonio. [cited 2015 3/2/2015]. Available from: www.solarsanantonio.org/wp-content/uploads/ 2013/04/Value-of-Solar-at-San-Antonio-03-13-2013.pdf.

26. Perez R, Hoff T. 2008. Energy and capacity valuation of photovoltaic power generation in New York. Clean Power Research, for the Solar Alliance and the New York Energy Industry Association. [cited 2015 3/2/2015]. Available from: www.asrc.cestm.albany. edu/perez/publications/UtilityPeakShavingandCapacityCredit/ PapersonPVLoadMatchingandEconomicEvaluation/ EnergyCapacityValuation-08.pdf.

27. Rocky Mountain Institute. 2013. A review of solar PV benefit \& cost studies. [cited 2015 3/2/2015]. Available from: www.rmi.org/ c m s/Download.asp x ? id = $10793 \&$ file $=$ e L a b DERBenefitCostDeck_2nd Edition\&title $=\mathrm{A}+$ Review + of + Solar + $\mathrm{PV}+$ Benefit + and $+\mathrm{Cos}+$ Studies.pdf. Compares the different approaches taken by prior VOS studies and demonstrates how their findings vary based on the types of variables 
included, the data sources and methodological approaches for quantifying those variables, and the assumed market penetration of solar energy, among other factors.

28. Keyes J, Rábago K. 2013. A regulator's guidebook: calculating the benefits and costs of distributed solar generation. [cited 2015 3/2/ 2015]. Available from: http://www.irecusa.org/wp-content/uploads/ 2013/10/IREC Rabago_Regulators-Guidebook-to-AssessingBenefits-and-Costs-of-DSG.pdf. Builds off of the Rocky Mountain Institute study to provide guidelines for state regulators who wish to evaluate the costs and benefits of solar energy.

29. Denholm P, et al. 2014. Methods for analyzing the benefits and costs of distributed photovoltaic generation to the U.S. electric utility system. National Renewable Energy Laboratory. [cited 2015 3/2/2015]. Available from: http://www.nrel.gov/docs/fy14osti/ 62447.pdf. Provides a highly detailed overview of the different research methods, data sources, and analysis tools used in VOS research.

30. Duke $\mathrm{R}$ et al. Accelerating residential PV expansion: demand analysis for competitive electricity markets. Energy Policy. 2005;33(15):1912-29.

31. Energy and Environmental Economics (E3). 2010. Introduction to the net energy metering cost effectiveness evaluation. Prepared for the California Public Utilities Commission. [cited 2015 3/2/2015]. Available from: http://www.cpuc.ca.gov/NR/rdonlyres/0F42385AFDBE-4B76-9AB3-E6AD522DB862/0/nem combined.pdf.

32. Energy and Environmental Economics (E3). 2011. California solar initiative cost-effectiveness evaluation. Prepared for the California Public Utilities Commission. [cited 2015 3/2/2015]. Available from: https://www.ethree.com/documents/CSI/CSI\%20Report_ Complete E3 Final.pdf.

33. Energy and Environmental Economics (E3). 2014. Nevada net energy metering impacts evaluation. Prepared for the State of Nevada Public Utilities Commission. [cited 2015 3/2/2015]. Available from: http://puc.nv.gov/uploadedFiles/pucnvgov/Content/About/ Media Outreach/Announcements/Announcements/E3\% 20PUCN̄\%20NEM\%20Report\%202014.pdf?pdf=Net-MeteringStudy.

34. Stanton E, et al. 2014. Net metering in Mississippi: Costs, benefits, and policy considerations. Synapse Energy Economics, Inc., for the Public Service Commission of Mississippi. [cited 2015 7/3/2015]. Available from: http://votesolar.org/wp-content/uploads/2014/10/ Synpase-MS.pdf

35. Beach R, McGuire P. 2013. The benefits and costs of solar distributed generation for Arizona public service. Crossborder Energy, prepared for Arizona Public Service. [cited 2015 3/2/2015]. Available from: www.seia.org/sites/default/files/resources/AZDistributed-Generation.pdf.

36. Beck R. 2009. Distributed renewable energy operating impacts and valuation study. For Arizona Public Service, 2009. [cited 2015 3/2/ 2015]. Available from: http://www.solarfuturearizona.com/ SolarDEStudy.pdf.

37. Navigant. 2010. Distributed generation study. Prepared for NV Energy. [cited 2015 3/2/2015]. Available from: www.navigant. com/ /media/WWW/Site/Insights/Energy/NVE_DG_Study_ Energy.ashx

38. Rábago K, et al. 2012. Designing Austin energy's solar tariff using a distributed PV value calculator. Clean Power Research, for Austin Energy. [cited 2015 3/2/2015]. Available from: http://www. c l e a n power.com/w p - content/uploads/0 90 DesigningAustinEnergysSolarTariff.pdf.

39. SAIC. 2013. 2013 updated solar PV value report. Prepared for Arizona Public Service. www.azsolarcenter.org/images/docs/ reports/SolarValueStudy-SAIC-2013-05.pdf.

40. XCEL Energy Services, Inc.. 2013. Costs and benefits of distributed solar generation on the Public Service Company of Colorado system. Study report in response to Colorado Public Utilities Commission Decision No. C09-1223. [cited 2015 3/2/2015]. Available from: http://votesolar.org/wp-content/uploads/2013/12/ 11M-426E_PSCo_DSG_StudyReport_052313.pdf.

41. Beach R, McGuire P. 2013. Evaluating the benefits and costs of net energy metering in California. Crossborder Energy, for Vote Solar. [cited 2015 4/27/2015]. Available from: http://votesolar.org/wpcontent/uploads/2013/01/Crossborder-Energy-CA-Net-MeteringCost-Benefit-Jan-2013-final.pdf.

42. Beach R, McGuire P. 2013. Benefits and costs of solar distributed generation for the public service company of Colorado. A critique of PSCo's distributed solar generation study. Crossborder Energy. [cited 2015 4/27/2015]. Available from: http://www.oursolarrights. org/files/5513/8662/3174/Crossborder_Study_of the_Benefits of_Distributed_Solar_Generation_for_PSCo.pdf.

43. Beach R, McGuire P. 2013. The benefits and costs of solar generation for electric ratepayers in North Carolina. Crossborder Energy, for the North Carolina Sustainable Energy Association. [cited 2015 4/27/2015]. Available from: www.energync.org/assets/files/ BenefitsandCostsofSolarGenerationforRatepayersinNorthCarolina. pdf.

44. Cliburn J, Bourg J. 2013. Ratemaking, solar value, and solar net energy metering - a primer. For the Solar Electric Power Association. [cited 2015 3/2/2015]. Available from: https://www. solarelectricpower.org/media/51299/sepa-nem-report-0713-print.pdf.

45. Weiss J, et al. 2012. The potential impact of solar PV on electricity markets in Texas. The Brattle Group, prepared for the Solar Energy Industries Association and the Energy Foundation. [cited 2015 3/2/ 2015]. Available from: www.seia.org/sites/default/files/ brattlegrouptexasstudy6-19-12-120619081828-phpapp01.pdf.

46. GE Energy Consulting. 2014. PJM renewable integration study, executive summary report. Prepared for PJM Interconnection, LLC. [cited 2015 1/7/2015]. Available from: http://www.pjm. com/committees-and-groups/subcommittees/irs/pris.aspx.

47. Contreras J, et al. 2008. Navigant consulting Inc., prepared for the national renewable energy laboratory. Photovoltaics value analysis. [cited 2015 3/2/2015]. Available from: http://www.eere.energy.gov/ solar/pdfs/42303.pdf.

48. Smeloff E. 2005. Quantifying the benefits of solar power for California. The Vote Solar Initiative. [cited 2015 3/2/2015]. Available from: http://www.energycollection.us/Energy-Solar/ Quantifying-The-Benefits.pdf.

49. Fine $\mathrm{S}$, et al. 2014. The true value of solar. ICF International. [cited 2015 3/2/2015]. Available from: http:/www.icfi.com/insights/ white-papers/2014/true-value-of-solar.

50. Missouri Energy Initiative. 2015. Net metering in Missouri: The benefits and the costs. [cited 2015 7/3/2015]. Available from: http://www.moenergy.org/publications/whitepapers/net-meteringin-missouri. http://www.moenergy.org/publications/whitepapers/ net-metering-in-missouri.

51. Pitt D, Michaud G. 2014. Analyzing the costs and benefits of distributed solar generation in Virginia. Virginia Distributed Solar Generation and Net Metering Stakeholder Group, prepared for the Virginia Department of Environmental Quality and the Virginia Department of Mines, Minerals and Energy. [cited 2015 4/27/ 2015]. Available from: http://mdvseia.org/wp-content/uploads/ 2014/12/SSG-Value-of-Solar-Study-Final-10-31-14.pdf.

52. Perez, et al. 2011. Solar power generation in the US: Too expensive, or a bargain? University at Albany, George Washington University, and Clean Power Research. [cited 2015 3/2/2015]. Available from: http://www.asrc.cestm.albany.edu/perez/2011/solval.pdf.

53. Mills A, Wiser R. 2012. Changes in the economic value of variable generation at high penetration levels: a pilot case study of California. Lawrence Berkeley National Laboratory. [cited 2015 3/2/2015]. Available from: http://eetd.lbl.gov/EA/EMP. 
54. New York State Energy Research and Development Authority. 2011. New York solar study. [cited 2015 3/2/2015]. Available from: www.nyserda.ny.gov/-/media/Files/Publications/Energy-Analysis/ NY-Solar-Study-Report.pdf.

55. Virginia State Corporation Commission. 2011. Response to net energy metering information request from the Virginia general assembly house commerce and labor special sub-committee on energy.

56. Vermont Public Service Department. 2013. Evaluation of net metering in Vermont conducted pursuant to act 125 of 2012. [cited 2015 3/2/2015]. Available from: http://www.leg.state.vt.us/reports/ 2013ExternalReports/285580.pdf.

57. Pacific Northwest National Laboratory. 2014. Duke Energy photovoltaic integration study: Carolinas service areas. [cited 2015 3/2/ 2015]. Available from: www.pnnl.gov/main/publications/external/ technical_reports/PNNL-23226.pdf.

58. Satchwell A, et al. 2014. Financial impacts of net-metered PV on utilities and ratepayers: a scoping study of two prototypical U.S. utilities. Lawrence Berkeley National Laboratory. [cited 2015 4/27/ 2015]. Available from: http://emp.lbl.gov/sites/all/files/LBNL\% 20PV\%20Business\%20Models\%20Report_no\%20report\% 20number $\% 20$ (Sept $\% 2025 \% 20$ revision).pdf.

59. NV Energy. 2015. Power facts. [cited 2015 4/27/2015]. Available from: https://www.nvenergy.com/company/facts.cfm.

60. Edison Electric Institute. 2014. Comments of the Edison Electric Institute net benefits and costs of distributed solar energy and innovative solar deployment models, DOE-EERE. [cited 2015 4/27/ 2015]. Available from: http://www.eei.org/issuesandpolicy/ t e s t i m o n y - f i li n g s - b r i e f s / D o c u m e n t s / 140228ComerDoeDistributedSolarEnergyCosts.pdf. Provides a detailed synopsis of the arguments that some electric utilities make against distributed solar PV.

61. Alam M et al. Mitigation of rooftop solar PV impacts and evening peak support by managing available capacity of distributed energy storage systems. IEEE Trans Power Syst. 2013;28(4):3874-84.

62. Craver T. Raising our game: distributed energy resources present opportunities - and challenges - for the electric utility industry. Electr Perspect. 2013;38(5):18-25.

63. Hernandez R et al. Environmental impacts of utility-scale solar energy. Renew Sust Energ Rev. 2014;29((NA):766-79.

64. Phillips J. Determining the sustainability of large-scale solar photovoltaic power plants. Renew Sust Energ Rev. 2013;27(NA)):435-44.
65. Turney D, Fthenakis V. Environmental impacts from the installation and operation of large-scale solar power plants. Renew Sust Energ Rev. 2011;15(6):3261-70.

66. Union of Concerned Scientists. 2009. Clean energy, green jobs: a national renewable electricity standard will boost the economy and protect the environment. [cited 2015 4/27/2015]. Available from: http://www.ucsusa.org/clean_energy/smart-energy-solutions/ increase-renewables/clean-energy-green-jobs.html\#. VT8T3iFViko.

67. National Renewable Energy Laboratory. 2013. Energy, economic, and environmental benefits of the Solar America initiative. [cited 2015 4/27/2015]. Available from: http:/www.nrel.gov/docs/ fy07osti/41998.pdf.

68. National Renewable Energy Laboratory. 2013. About JEDI models. [cited 2015 4/27/2015]. Available from: http:/www.nrel.gov/ analysis/jedi/about jedi.html.

69. Industrial Economics, Inc. 2015. Assessment of the economy-wide employment impacts of EPA's proposed Clean Power Plan. [cited 2015 4/27/2015]. Available from: http://www.inforum.umd.edu/papers/otherstudies/2015/iec inforum report 041415.pdf.

70. Meister Consultants Group. 2015. Assessing Virginia's energy future: employment impacts of Clean Power Plan compliance scenarios. Prepared for the Advanced Energy Economy Institute and the Virginia Advanced Energy Industries Coalition. [cited 2015 4/27/2015]. Available from: https://d 3 n 8 a 8 pro 7 vh mx. c loudfront.net/ virginiaadvancedenergy/pages/52/attachments/original/ 1429107935/AEEI-VAEIC-VA-energy-future-Final.pdf? 1429107935

71. Interstate Renewable Energy Council. 2014. U.S. solar market trends, 2013. [cited 2015 4/27/2015]. Available from: http://www. irecusa.org/annual-u-s-solar-market-trends-report/.

72. U.S. Energy Information Administration. 2015. International energy statistics, total electricity installed capacity. [cited 2015 4/27/ 2015]. Available from: http://www.eia.gov/cfapps/ipdbproject/ IEDIndex3.cfm?tid $=2$ \&pid $=2$ \&aid $=7$.

73. U.S. Energy Information Administration. 2015. Monthly energy review, January 2015, Table 7.2a, electricity net generation: total (all sectors). [cited 2015 4/27/2015]. Available from: http://www. eia.gov/totalenergy/data/monthly/index.cfm\#electricity. 